\title{
The Use of Anti-Language to Improve The Ability of Elementary Students of Grade 5 in Understanding The English Grammar
}

\author{
Mery Silalahi \\ Universitas Sari Mutiara Indonesia \\ Medan, Indonesia \\ mery.silalahi@yahoo.com
}

\begin{abstract}
Studying English as a foreign language, makes learning English difficult to understand, coupled with grammar that is complicated and far different from our native language, Indonesian. The formulation patterns found in grammar usually have to be memorized by students, but most students memorize just to be able to answer questions in English lessons only. The formulation in grammar usually forms a monotonous pattern that is difficult to memorize. The activity of changing the formula contained in English grammar into words, sentences, and abbreviations that is unique and funny will form an antilanguage that can be created by students in accordance with the creativity of each student. This research was conducted by using a qualitative approach, which examine the process of learning English grammar using anti-language method that took place for elementary students of grade $\mathrm{V}$ in SD Asisi Medan. This study also produced data on apperception, exploration, discussion and explanation of concepts, as well as the development and application of the antilanguage method for English grammar on elementary students of grade $\mathrm{V}$ in SD Asisi Medan. The data is generated through observations of student learning activities and teacher performance conducted during the learning of English grammar takes place. The description and summary of various conditions or situations that occur during the learning process in the classroom, then described in writing as a form of research results.
\end{abstract}

\section{Keywords-anti-language; english; grammar}

\section{INTRODUCTION}

The role of grammar knowledge in learning and teaching English has become an important thing to note, especially by English teachers. In Indonesia, we often allow language mistakes to be understandable because Indonesians themselves may not necessarily be able to correct and do not like to be corrected in terms of language. [1] emphasized that knowledge of grammar can help students to correct language errors in English both verbally and in writing. Grammar that must be studied includes Morphology (how to form words), Syntax (sentence rules), Semantics (understanding of meaning), Pragmatics (meaning of context), Phonetics (sounds and symbols), and Phonology (way of speaking). All of these are aspects that need to be learned in mastering English grammar.
The best way to understand and use grammar is through a combination of two methods - analysis and inference, namely by thinking of a pattern. There are patterns in grammar that must be learned and even memorized by students in learning English. This ultimately makes students no longer interested in learning English. This pattern forms a complex formula that prevents students from learning English. As for students who learn grammar only to be able to answer questions in English. Grammar patterns in English that are difficult to understand make students more comfortable learning English in a place that specializes in teaching conversations. This makes grammar seem unimportant. Even though English sentences cannot be separated from grammar rules.

Based on the problems mentioned above, the researchers hope that there is a method that can make students learn and memorize grammar quickly and easily. Difficulties faced by students tend to have to remember or memorize the patterns found in grammar. If the pattern can be replaced with pronouns or sentences that are easy to remember, which can be words or sentences that lead to something funny and unique, and can also be made with abbreviations, then any formula presented in the grammar will be easy to be remembered. Because basically the pronouns or abbreviations made to facilitate students in remembering the formulation patterns contained in English grammar, can be created by themselves according to student creativity. To remember something in long term memory, students must be able to train the right brain to work optimally, where the right brain thinking according to [2] is more random, irregular, intuitive, holistic, and nonverbal. [2] also asserts that the right brain functions in creativity, recognition of shapes, patterns, rhythm, imagination, spatial images, colors, and abstract domains. Therefore, if you want to store long-term memory in the right brain, information about grammar (in the form of formulations), must be converted into words, sentences, or abbreviations that are funny and unique. Because the right brain will usually easily catch and store something funny and unique in our memory. 
The formulas in English grammar which are converted into words, sentences, or funny and unique abbreviations are antilanguage because they are self-created, as they wish according to the creativity of each student. Thus, because this is students' own creativity, memorization can be a fun activity for them, so students become excited and interested in learning grammar.

The term anti-language was first introduced by linguists [3] where he argued that anti-language is a language code created and used by the community or antisocial community who deliberately created antilanguage as a means of communication to prevent outsiders from understanding their communication. This anti-language includes strange and absurd words and sentences that are hardly understood by outsiders. The more anti-language terms the community has, the more difficult it is for outsiders to understand.

Anti-language is different from slang and jargon. Antilanguage uses unusual vocabulary or grammar such as borrowing words from other languages, utilizing new suffixes for existing words, and changing word formations such as apple (in English) to change into elppa. This makes antilanguage different and unique. As discussed in the previous paragraph, that students have difficulty in learning and memorizing English grammar, the use of anti-language is expected to be the best solution to help students memorize formulas for English grammar formulas. The formula contained in English grammar will be changed into different language codes, unique and funny, creating a new antilanguage language, but will be more remembered by the human right brain which tends to absorb something unique and funny in the long term memory.

\section{LITERATURE REVIEW}

\section{A. Grammar}

Grammar serves to describe the structure of language and the way how linguistic units such as words and phrases are combined to produce sentences in language [4]. [5] describes three grammars that must be learned in learning English. First, traditional grammar (grammar), which focuses on the rules in making the correct sentence. Second, formal grammar, which aims to describe sentence structures. And the third is functional grammar, which functions to describe language as meaning whose focus is on the text and context.

Grammar covers grammatical patterns of sentences. Grammar can also be interpreted as a form of speech that is formulated (William Somerset Maugham, The Summing Up, 1938). Grammar is referred to as the structural foundation of a language. Therefore, our knowledge of grammar will help us effectively use language, especially when it comes to writing. A good understanding of grammar can help us understand meaning (David Crystal, "In Words and Acts," TES Teacher, April 30, 2004). The grammar rules in language are determined by the nature of the language itself but the rules of language use and appropriateness are determined by the language community (Joseph C. Mukalel, Approach to Teaching English. Discovery Publishing House, 1998). Grammar is related to rules. The rule is about using words, phrases, clauses and sentences.

On the other hand, grammar lays out the rules about using language that is "right" or "wrong". The current grammar system is codified. It is intended that people can understand grammar through existing documents, and so that grammar can be taught with the same rules. When the rules in grammar are no longer used in a language, then this is what later in the course of time will form a new language.

\section{B. Pronoun}

According to Abia (2013), Pronoun is seen as a grammatical item that functions as a substitute for nouns and noun phrases. Pronoun is one of the building blocks in a sentence. Pronoun is also used to avoid unnecessary repetition of nouns in writing. Examples of unnecessary repetition in an English text are for example: Mary is in Mary's office, but Mary was asked not to be interrupted. In this case, the pronoun can be used to eliminate the repetition that occurs in the sentence, which is: Mary is in her office, but she was asked not to be interrupted.

Pronoun in English grammar can be categorized into three principles, namely: (a) Person (b) Number (c) Gender. In the context of Person, pronoun refers to the role played in a conversation activity. In other words, this implies that in any conversation situation, there are 3 (three) characters that can be observed namely: (first person, second person and third person). (I, Me, My, Mine, We, Us, Our, and Ours).

According to Okunowo (2014), the first person is seen as the person who is speaking or the speaker. Example: (I, Me, My, Mine, We, Us, Our, and Ours); the second person is seen as the person spoken to, namely the listener, namely: (You, You, Your, Yours) and the third person is seen as the person who is talking, namely: (It, They, Them, Their, Theirs)

Furthermore, in the context of Number, pronoun refers to numerical differences made for characters involved in speech activities. In this way, pronoun has a singular and plural form. For example: (I and We; Me and Us; He, She, It and They; and You). Whereas in the Gender context, pronouns are categorized according to the sex of the characters involved in speech activities, such as for naming men, women, women in generalization cases and for naming a place, object or event. For example in English grammar, namely: masculine / male (He, Him), feminine / female (She, Her), neuter / neutral (I, Me, It, Its), and generic / general (his, her).

Pronoun in English grammar consists of personal pronoun. Personal pronoun refers to people and things; can be in the singular or plural form, and the shape can change according to the grammatical function in the sentence. Adapted from The Little Brown Compact Handbook, 3rd Ed., J.E. Aaron, M. McArthur, personal pronoun is used to replace the sentence subject (pronoun as subject [subjective]), the object of the 
sentence (pronoun as object [objective]), and the form of belonging in the sentence (possessive pronoun).

Pronoun as subject is used as a substitute for the subject in the sentence, namely: I, You, He, She, It, We, and They. Pronoun as object is used instead of objects in sentences, namely: Me, You, Him, Her, It, Us, Them. And the possessive pronoun shows ownership. For example: Mine, Its, Hers, His, Yours, Ours, and Theirs.

Next, there is a demonstrative pronoun which is used to identify nouns (something specific in a sentence). There are only four demonstrative pronouns in English grammar, namely: this, that, these, and those. If translated in Indonesian then it only has two meanings, namely "this and that". This and that are used as demonstrative pronoun in the singular, while these and those are used as demonstrative pronoun in plural. Examples of demonstrative pronouns in the following sentence are printed in bold to facilitate identification, namely: (a) This lab report is due tomorrow, (b) That looks like the computer I used to have, (c) Put these pencils on your desk, (d) Those were the best days of my life.

\section{Anti-language}

The role of language is very important in human life. By language, communication runs easily, smoothly, practically and economically. According to [6], effective communication can occur if each speaker masters the difference in planguage diversity. Variety of languages based on speakers and their use with respect to the status, class, and class of speakers, which are usually called acoustic, basilek, vulgar, slang, colloquial, jargon, argot, ken and prokem In a variety of languages, a language may experience word changes so that it has new meaning. Every change there is a noticeable difference, as in writing and pronunciation. Changes that occur in this language then become the initial concept of thinking [3] on antilanguage. [3] defines anti-language as a way of communicating a group of people to prevent outsiders from understanding their communication.

Anti-language can also be understood as an extreme version of social dialect because the community uses the same grammar as in general languages, but tells it in a different way. Anti-language is designed by forming new words or searching for a word equivalent. In addition, anti-language can be created by itself into an innovation in language. The point is to find new words or use old words to represent new meanings.

Another type of anti-language formation is the abbreviation. Abbreviations can be taken from a group of letters from a word or phrase. Abbreviations or also called acronyms were actually created to save time and speed up the typing / writing process, but now the abbreviation has become a trend among the younger generation [7]. As time passes marked by technological developments, anti-language is developing rapidly and its form is becoming more and more diverse. Anti-language is often used in social media and daily conversation. Shifts in word structure that occur at the present time have formed the emergence of new vocabulary that marginalizes formality in language. There is an increase in the number of new words that appear from day to day. In fact there is no specific formula in the formation of antilanguage.

Research about Anti-language is indeed not as much as other social-linguistic research that studies language codes or language styles. This might happen because there are still very few references available regarding anti-language. However, this does not dampen the intention of [8] to investigate this anti-language. In his article entitled "The Analysis of AntiLanguage from the Perspective of Current Situation of Netspeak"), the author tries to analyze the use of anti-language by Chinese netizens on internet social media and how the netijen perspective on the use of anti-language is.

In addition, other researchers who associate their research with anti-language are [9]. In his article entitled "Language, Power, and Resistance: Study of the Names of Business Entities in DI Yogyakarta", the author discusses the Indonesian Language Resistance to Foreign Languages to maintain Indonesian as the national language of the nation. This research focuses on the language used to name business entities in Yogyakarta. Here, naming for Business Entities tends to use languages adapted from foreign languages, such as English, French, Japanese, and others. The researcher observes how to maintain Indonesian among these foreign languages, namely by forming a new language (antilanguage), where Indonesian language is combined with a foreign language which then displays a unique language and only a certain community will realize the meaning from the antilanguage.

Anti-language is also understood as an extreme version of social dialect. Moving on from that statement, [10] then conducted an investigation of the anti-language used by marginal people in Madura, where their language was known as Ken and Argot Madura. In this research, the researcher explains that anti-language uses the same grammar as in general languages, but the people who speak this antilanguage (Madurese) use the grammar in different ways so that their language can only be understood by people people who are in the anti-language circle.

From this explanation, without us knowing, anti-language is actually often used in our daily lives. Anti-language forms new vocabulary that is only understood by certain people. Anti-language is growing among millennials today. Current technological developments along with the development of anti-language. This phenomenon then becomes a very interesting topic for research by researchers.

Regarding previous studies which have already been carried out by other researchers both domestically and abroad on anti-language, then further studies examining anti-language are expected to be more developed and the numbers can increase more and more.

Likewise in this study, it is expected to make a useful contribution to the world of education. In this study, antilanguage is used as a way for students to develop themselves 
in understanding English grammar to be easier for the elementary students of grade 5 SD Asisi Medan.

\section{RESULT AND DISCUSSION}

In this study, researchers act as teachers who provide subject matter and are accompanied by a collaborator who will observe and record certain behaviors during the teaching and learning process. From observations that have been made, there are some things that should be noted indeed appear, namely during the initial session of giving material using antilanguage, students are seen trying to synthesize their ideas and relate them to the grammar being studied. In this case, the enthusiasm of students is very high. This is evidenced by voice chat, a series of movements and even laughter issued by students shows that students are very enthusiastic in looking for ideas to create their own anti-language.

Students are given material about Pronoun (pronouns). Sub material in pronoun consists of: personal pronoun (pronouns people); that is, consisting of: subject, object, and possessive pronouns, and demonstrative pronouns. Students listen and try to understand the material presented by researchers. The pronoun material looks very difficult for students to understand because there are many vocabularies that look and sound the same in their writing and pronunciation. Researchers give direction to students to try to memorize pronoun formulas that have been explained. Starting from personal pronoun as subject. These subject pronouns consist of: I, You, We, They, He, She, It. Students look very difficult in memorizing it. The researcher then directs the students to form an anti-language based on the personal pronoun as the subject. Students then find a unique anti-language to memorize personal pronoun as subject, namely: "AYuDeWi SiHIte". Ay for I, Yu for You, De for They, Wi for We, Si for She, and HIte for He and It.

Next to personal pronoun as object that consists of: me, you, us, them, her, him, and it. In the same way, students also try to find anti-language for this personal pronoun as object group. First of all, students change their pronunciation, namely: from English to Indonesian, so me becomes mi, you become yu, us becomes as, them become dem, her remains her, and so with him and it stays with the same pronunciation . The anti-language formed for the personal pronoun as object group is "DeMi HiYu TERAS". De for them, Mi for me, Hi for he and his, Yu for you, TER for it and her, and finally US for us.

Still in the same way, students then also sought antilanguage for possessive pronouns, namely: my, your, our, their, her, his, and its. Students start by changing the pronunciation first, so that my becomes mai, your becomes yor, his remains his, they become deir, her remains her, and so is its fixed with the same pronunciation. Antilanguage formed for this possessive pronoun is: "MaYor DeWer TERHITS". May for my, Yor for your, De for them, Wer for our, TER for it and her, HITS for his and its.

For demonstrative pronoun, which consists of this, that, these, and those. The pronunciation of this, that, these, and those is changed to Indonesian language: dis, ded, diz, and doz. Anti-language formed for the demonstrative pronoun is: "DeDis and DoDiz". De for that, Dis for this, Do for those, and Diz for these.

This method should be very effective to be carried out together (cooperative learning). One group of students will look for ideas to create their own anti-language after seeing the formulation contained in English grammar. They form their anti-language based on words or terms that they often hear through television and internet media, that is, which are currently in the present. Another group of students formed their anti-language based on words that were happily offered by artists who were hits on television. There are still other groups that present a new term to become their own antilanguage based on a systematic word order based on the existing grammar formulation. In this case, it appears that students build strong interactions between one student and another student. Each student sends information to other students about the language ideas they find. All students seem to want to show themselves to be able to form anti-language that is interesting, easy to remember, and at least useful for a long period of time each time they remember the formula in grammar. The application of anti-language to improve English grammar allows the improvement of children's thinking skills. The benefits that the child initially receives are accidental but meaningful.

The study also found that some students looked happy when given the opportunity to be creative and artistic. This has a positive impact on the learning process. When children are happy, any material being studied will be more easily absorbed. Other students indicated that they were building constructive ways of thinking, that is, where students could find ways to solve problems they experienced while learning. This means that the way they shape the anti-language for the existing grammar formulation, also significantly helps them to better understand the concepts being studied. Still with the same group of students, which shows that the opportunity to work together in teams with peers is also the reason for the ability to think constructively well stimulated. As [12] argues that social aspects are needed in the learning process, this is also shown by students where one student needs other students to help solve problems experienced during learning.

Based on the explanation above, the learning model offered in this study is referring to the constructivism learning model. According to Vygotsky, children are seen as active seekers of knowledge. Through antilanguage created by children, children are formed to be creative. Children will form their own anti-language based on experiences gained from their environment. Anti-language is easier to remember because children who form creative ideas create unique words that are only understood and understood by themselves, Vygotsky states that children interact together with the environment. This affects the cognitive development of children because knowledge is constructed through children's social interaction experiences in their environment. 


\section{REFERENCES}

[1] Debata, P. K. (2013). The Importance of Grammar in English Language Teaching.Language in India.

[2] De Potter,Bobby. (1999) Quantum Learning. Bandung: Kaifa.

[3] Halliday, M. A. K.1976. "AntiLanguages". American Anthropologist 78 (3) pp. 570-584

[4] Richards, J. C., dan Schmidt, R. 2002. Longman Dictionary of Language Teaching and Applied Linguistics. London: Longman Pearson Education.

[5] Gerot, Linda and Wignell, Peter. 1995. Making Sense of Functional Grammar. NSW: Antipodean educational Enterprises.

[6] Prayitno. 2004. Layanan Bimbingan Kelompok Dan Konseling Kelompok. Padang: Universitas Negeri Padang.

[7] Crystal, David. 2001. Language and the Internet. United Kingdom: Cambridge University Press.
[8] Shi Baihui, Li Fengjie. 2017. The Analysis of Anti-language from the Perspective of Current Situation of Netspeak. International Journal of Language and Linguistics. Vol. 5, No. 2, 2017, pp. 50-56. doi: 10.11648/j.ij11.20170502.14

[9] Putu Wijana, I Dewa. 2014. Bahasa, Kuasa, dan Resistensinya: Studi tentang Nama-Nama Badan Usaha di D.I Yogyakarta. Vol. 26, pp. 5664.

[10] Nurul Azhar, Iqbal. 2017. Ken dan Argot Madura: Antibahasa OrangOrang Marjinal. Prosiding Seminar Nasional Bahasa dan Sastra (Senabastra) Ix, Contemporary Issues InLanguage, Literature, And Education. pp. 105-118. Program Studi Sastra Inggris Universitas Trunojoyo Madura ISBN 978602-1850-62-6

[11] Lexy J. Moleong. 2005. Metodologi penelitian kualitatif, Bandung: Remaja Rosdakarya

[12] Given, L. M. (2008). The Sage Encyclopedia of Qualitative Research Methods. Thousand Oaks: Sage. 